\title{
PELAKSANAAN LELANG BARANG RAMPASAN BERDASARKAN PUTUSAN YANG TELAH BERKEKUATAN HUKUM TETAP (Studi di Kejaksaan Negeri Kota Kediri)
}

\author{
Ilham Syahputra Prabandaru \\ Fakultas Hukum Universitas Islam Kadiri, Kediri \\ prabandaruilham@gmail.com
}

\begin{abstract}
This study discusses the implementation of a booty auction based on a decision that has a permanent legal force (Study at judiciary the Kediri). This problem is motivated by the implementation of a booty auction based on a decision that has permanent legal force carried out by District Attorney the Kediri which has been in accordance with the prevailing laws and regulations but the effectiveness of the implementation itself is not too good due to several obstacles inside it. The limitation of the problem in this study, namely how the auction of booty based on a decision that has permanent legal force carried out by the judiciary of District Attorney and what factors become obstacles in the implementation of a booty auction based on a decision that has permanent legal force carried out by the Public District Attorney of Kediri. This type of research is empirical juridical, namely by reviewing the applicable legal provisions and the reality in the community. The study argues that the weak effectiveness of the booty auction is due to the length of time required by the parties involved in the process of completing an auction of goods the spoils as well as other factors such as the State Wealth and Auction Service Office (KPKNL), the effectiveness of the Malang Regional KPKNL performance, the costs of booty, the economic value of the booty.
\end{abstract}

Keywords : Auction, Goods Confiscated, Permanent Legal Force. ${ }^{l}$

${ }^{1}$ Submit : 2-11-2018, Editing-1: 5-11-2018, Review-1, Iskandar Muda, SH., MH : 9-11-2018. Review-2, Nandang Sutrisno, S.H., M.Hum., LLM., Ph.D : 17-11-2018, Editing-2: 30-11-2018, Production: 30-11-2018. 


\begin{abstract}
ABSTRAK
Studi ini membahas tentang pelaksanaan lelang barang rampasan berdasarkan putusan yang telah berkekuatan hukum tetap (Studi di Kejaksaan Negeri Kota Kediri). Latar belakang permaslahnnya adalah terkait pelaksanaan lelang barang rampasan berdasarkan putusan yang telah berkekuatan hukum tetap yang dilakukan oleh Kejaksaan Negeri Kota Kediri yang selama ini sudah sesuai dengan peraturan perundang-undangan yang berlaku, namun efektifitas dari pelaksanaan itu sendiri bisa dikatakan tidak terlalu baik disebabkan beberapa faktor yang menjadi kendala didalamnya. Adapun batasan masalah dalam penelitian ini, yaitu bagaimana pelaksanaan lelang barang rampasan berdasarkan putusan yang telah berkekuatan hukum tetap yang dilakukan oleh Kejaksaan Negeri Kota Kediri, serta Faktor apa yang menjadi hambatan dalam pelaksanaan lelang barang rampasan berdasarkan putusan yang telah berkekuatan hukum tetap yang dilakukan oleh Kejaksaan Negeri Kota Kediri. Jenis penelitian ini adalah yuridis empiris yaitu dengan mengkaji dari ketentuan hukum yang berlaku dan kenyataan yang ada dimasyarakat. Hasil studi mengungkapkan bahwa lemahnya efektifitas dari pelaksanaan lelang barang rampasan tersebut disebabkan oleh lamanya waktu yang dibutuhkan oleh pihak-pihak yang terkait dalam proses penyelesaian suatu lelang terhadap barang rampasan tersebut serta faktor lainnya seperti tempat Kantor Pelayanan Kekayaan Negara dan Lelang (KPKNL), Efektivitas kinerja KPKNL Wilayah Malang, biaya terhadap barang rampasan, nilai ekonomis barang rampasan.
\end{abstract}

Kata Kunci : Lelang, Barang Rampasan, Kekuatan Hukum Tetap. 


\section{Pendahuluan}

Keadilan selalu mengandung unsur penghargaan, penilaian atau pertimbangan dan karena itu lazim dilambangkan dengan suatu neraca keadilan. ${ }^{2}$ Pernyataan di atas, menjelaskan bahwa agar tata-tertib dalam masyarakat itu tetap terpelihara, maka haruslah adanya keadilan supaya kaedah-kaedah hukum itu dapat ditaati oleh masyarakat, akan tetapi pada praktiknya tidaklah semua orang mau menaati kaedah-kaedah hukum itu. Agar supaya sesuatu peraturan hidup dimasyrakat, benar-benar dipatuhi dan ditaati sehingga menjadi kaedah hukum maka peraturan hidup itu harus dilengkapi dengan unsur memaksa, dengan demikian hukum itu mempunyai sifat mengatur dan memaksa. Ia merupakan peraturan-peraturan hidup kemasyarakatan yang dapat memaksa orang supaya mentaati tata-tertib dalam masyarakat serta memberikan sanksi/hukuman yang tegas terhadap siapa yang tidak mau patuh mentaatinya. ${ }^{3}$

Menurut ketentuan Pasal 10 Kitab Undang-Undang Hukum Pidana (KUHP) terdapat beberapa jenis hukuman yang dapat dijatuhkan pada seseorang yang telah melakukan tindak pidana, di mana hukuman yang akan dijatuhkan itu dapat berupa Pidana pokok terdiri dari Pidana mati, Pidana penjara, Kurungan, Denda sementara Pidana Tambahan terdiri dari Pencabutan hak-hak tertentu, Perampasan barang-barang tertentu, Pengumuman putusan hakim. ${ }^{4}$ Untuk pidana tambahan berupa rampasan barang-barang tertentu pelaksanaannya itu dilakukan oleh pihak jurusita dan pihak kejaksaan bagian eksekutor. Barang-barang tertentu yang dilakukan perampasan itu berdasarkan keputusan dari Kejaksaan Agung Republik Indonesia itu dapat dilakukan lelang, dimanfaatkan oleh pemerintah untuk kepentingan Negara atau Sosial atau dimusnahkan. ${ }^{5}$

\footnotetext{
${ }^{2}$ C.S.T. Kansil, Pengantar Ilmu Hukum Dan Tata Hukum Indonesia, Cetakan ketiga, Bandung: PN Balai Pustaka ,1980, hlm 39.

${ }^{3}$ Ibid., hlm 40.

${ }^{4}$ Laden Marpaung, Proses Penanganan Perkara Pidana Cetakan pertama, Jakarta: Sinar Grafika, 2010, hlm. 216

${ }^{5}$ Teguh Prasetyo, Hukum Pidana, cetakan kelima, Jakarta: Rajawali Pers, 2014, hlm. 117
} 
Dalam peraturan pelaksanaan lelang barang rampasan menurut Surat Edaran Nomor : SE-03/B/B.5/8/1988 tentang penyelesaian Barang Rampasan, dijelaskan bahwa pelaksanaan lelang harus selesai dalam jangka waktu 4 (empat) bulan, namun pada praktiknya dijumpai sering adanya keterlambatan dalam prosesnya, hal tersebut terlihat ketika Kejaksaan Negeri Kota Kediri mengirimkan berkasberkas atau meminta surat permohonan lelang dengan cara mengirimkan melalui kantor pos atau dengan e-mail tanggapan dari Kantor Pelayanan Kekayaan Negara dan Lelang (KPKNL) begitu lama bahkan bisa sampai 1 (satu) bulan belum juga ada tanggapan sehingga Kejaksaan Negeri Kota Kediri perlu ke KPKNL Wilayah Malang secara langsung.

Mungkin secara prosedural ini terlihat remeh, namun dari praktik yang seperti inilah yang akhirnya menimbulkan kasus-kasus kecurangan dalam praktik lelang barang perampasan tersebut, contohnya seperti oknum Kepolisian Kediri Kota yang membeli sebuah mobil tipe sedan dengan merk Honda jazz dari pihak Kejaksaan yang didapat dari hasil lelang barang rampasan dengan harga murah dan tidak sesuai dengan harga pasaran serta tanpa Buku Pemilik Kendaraan Bermotor (BPKB). Dalam kasus ini, terdapat pelanggaran dalam proses pelelangan yang dilakukan oleh Kejaksaan terhadap barang rampasan yang pada praktiknya bertentangan dengan prosedur atau tata cara yang sesuai dengan peraturan perundan-undangan yang berlaku.

Penelitian yang membahas tentang pelaksanaan lelang barang rampasan berdasarkan putusan yang telah berkekuatan hukum tetap secara umum cukup banyak dilakukan oleh para peneliti terdahulu. Berdasarkan hasil penelusuran terhadap beberapa literatur yang telah dilakukan, maka setidaknya ditemukan beberapa literatur yang membahas mengenai permasalahan ini. ${ }^{6}$

Pertama, Mohammad Fajar Mahardika dengan judul Pelaksanaan pengelolaan benda sitaan Negara dan barang rampasan Negara oleh lembaga

\footnotetext{
${ }^{6}$ Kajian pustaka dalam penelitian ini menjadikan tolak ukur originalitas penelitiannya pada dua aspek, yaitu : kajian penelitian serta hasil atau temuan dalam penelitian tersebut.
} 
rumah penyimpanan benda sitaan Negara (RUPBASAN) kelas 1 Jakarta Timur. Penelitian tersebut mengkaji tentang bagaimana pelaksanaan pengelolan benda sitaan Negara dan barang rampasan Negara oleh Rupbasan kelas 1 Jakarta Timur serta kendala yang timbul dari pengelolaan benda sitaan Negara dan barang rampasan Negara oleh Rupbasan kelas 1 Jakarta Timur dan bagaimana upaya mengatasinya. ${ }^{7}$

Kedua, Tri Wahyuni dengan judul tinjauan tentang pelaksanaan pengelolaan benda sitaan Negara dan barang rampasan Negara oleh lembaga RUPBASAN Surakarta. Penelitian tersebut mengkaji tentang bagaimana mekanisme pelaksanaan pengelolaan benda sitaan Negara dan barang rampasan Negara di RUPBASAN Surakarta serta kendala yang timbul dalam pelaksanaan pengelolaan benda sitaan Negara dan barang rampasan Negara di RUPBASAN Surakarta dan upaya penyelesaiannya. ${ }^{8}$

Berdasarkan pemaparan beberapa penelitian di atas, maka dapat dinyatakan bahwa telah terdapat penelitian pelaksanaan lelang barang rampasan berdasarkan putusan yang telah berkekuatan hukum tetap khususnya yang berdasarkan pada kerangka yuridis emperis.

Jika dibandingkan dengan beberapa penelitian terdahulu, maka dapat diketahui bahwa letak perbedaannya terdapat pada lokasi penelitian serta batasan masalah yang digunakan dalam penelitian, yaitu pada pelaksanaan lelang barang rampasan yang telah mempunyai kekuatan hukum tetap yang dilakukan oleh Kejaksaan Negeri Kota Kediri serta faktor yang menjadi hambatan dalam pelaksanaan lelang barang rampasan berdasarkan putusan yang telah berkekuatan hukum tetap yang dilakukan oleh Kejaksaan Negeri Kota Kediri.

${ }^{7}$ Moh. Fajar Mahardhika, Pelaksanaan Pengelolaan Benda Sitaan dan Barang Rampasan Negara oleh Lembaga Rumah Penyimpanan Benda Sitaan Negara (Rupbasan) Kelas I Jakarta Timur, Skripsi, Fakultas Hukum Universitas Andalas Padang, 2017, hlm. 7

${ }^{8}$ Tri Wahyuni, Tinjauan Tentang Pelaksanaan Pengelolaan Benda Sitaan Negara dan Barang Rampasan Negara di Rumah Penyimpanan Benda Sitaan Negara (Rupbasan) Surakarta, Skripsi, Fakultas Hukum Universitas Sebelas Maret Surakarta, 2008, hlm. xii 


\section{Rumusan Masalah}

2.1. Bagaimana pelaksanaan lelang barang rampasan berdasarkan putusan yang telah berkekuatan hukum tetap yang dilakukan oleh Kejaksaan Negeri Kota Kediri.

2.2. Faktor apa yang menjadi hambatan dalam pelaksanaan lelang barang rampasan berdasarkan putusan yang telah berkekuatan hukum tetap yang dilakukan oleh Kejaksaan Negeri Kota Kediri

\section{Metode Penelitian}

\subsection{Jenis Penelitian}

Jenis penelitian yang digunakan dalam penelitian ini adalah yuridis empiris yaitu dengan mengkaji dari ketentuan hukum yang berlaku dan kenyataan yang ada dimasyarakat mengenai pelaksanaan lelang barang rampasan yang telah mempunyai kekuatan hukum tetap yang dilakukan oleh Kejaksaan Negeri Kota Kediri.

\subsection{Pendekatan Penelitian.}

Adapun pendekatan yang digunakan dalam mengkaji permasalahan di atas adalah pendekatan kasus. Dalam pendekatan kasus, yang perlu dipahami adalah ratio decidendi, yaitu alasan-alasan hukum yang digunakan oleh hakim untuk sampai kepada suatu putusan. Menurut Goodheart, ratio decidendi dapat ditemukan dalam memperhatikan fakta materiel. Perlunya fakta tesebut diperhatian karena baik hakim maupun para pihak akan mencari aturan hukum yang tepat untuk dapat diterapkan pada fakta tersebut. Ratio decidendi inilah yang menunjukkan bahwa ilmu hukum merupakan ilmu yang bersifat preskriptif, bukan deskriptif. Adapun diktum, yaitu putusannya merupakan sesuatu yang bersifat deskriptif. Oleh karena itulah pendekatan kasus bukanlah merujuk pada diktum putusan hakim melainkan 
pada ratio decidendinya. ${ }^{9}$ Atas dasar inilah dinjadikan pendekatan kasus sebagai salah satu bentuk pendekatan dalam penelitian ini karena dinilai pendekatan ini sangat cocok dalam mengungkap adanya korelasi antara .kurang efektifnya dari pelaksanaan lelang barang rampasan di Kejaksaan Negeri Kota Kediri dengan lambannya proses penyelesaian lelang yang dilakukan oleh Kejaksaan terhadap barang rampasan.

\subsection{Lokasi Penelitian.}

Lokasi peneletian adalah tempat dimana dilakukannya pengamatan untuk melakukan suatu penelitian mencari data yang diperlukan untuk peneletian. Penelitian dilakukan di Kejaksaan Negeri Kota Kediri Provinsi Jawa Timur.

\subsection{Bahan Hukum.}

3.4.1. Bahan hukum primer, peraturan perundang-undangan dan peraturanperaturan lain yang terkait dengan penelitian ini.

3.4.2. Bahan hukum sekunder, berupa buku-buku, artikel, jurnal ataupun karya ilmiah lain yang terkait dengan penelitian ini.

3.4.3. Bahan non-hukum, berupa kamus bahasa, kamus hukum serta bahanbahan bantu lain sebagai pendukung penelitian.

\subsection{Teknik Pengumpulan Bahan Hukum.}

3.5.1. Inventarisasi, yaitu dengan mencari dan mengumpulakan dokumendokumen dan bahan-bahan pustaka, baik itu berupa peraturan perundang-undangan ataupun berupa literatur ilmiah yang kemudian diseleksi sesuai dengan pembahasan dalam penelitian ini.

3.5.2. Identifikasi bahan hukum, yaitu menetapkan kriteria identifikasi untuk menyeleksi norma-norma yang termasuk hukum positif atau norma sosial yang bukan norma hukum.

3.5.3. Observasi, yaitu melihat dan mencermati prosedur dan pelaksanaan lelang barang rampasan di Kejaksaan Negeri Kota Kediri.

\footnotetext{
9 Peter Mahmud Marzuki, Penelitian Hukum, Edisi Revisi, cetakan ke sembilan, Jakarta : Prenadamedia, 2014, hlm. 159
} 


\section{Pembahasan dan Analisa}

\subsection{Ketentuan lelang dalam hukum positif Indonesia}

Kata lelang diambil dari kata adalah Auctio, yang artinya peningkatan secara bertahap. Berbeda dengan jual beli, lelang merupakan penjualan umum atau penjualan barang-barang yang dilakukan kepada umum dengan harga penawaran yang meningkat atau menurun atau kepada orang yang diundang atau sebelumnya diberitahu mengenai pelelangan atau penjualan itu, atau diijinkan untuk ikut serta dan diberi kesempatan untuk menawar harga, menyetujui harga yang ditawarkan.

Menurut Pasal 1 sub 17 Undang-Undang Nomor 19 Tahun 2000 tentang Penagihan Pajak dengan Surat Paksa disebutkan bahwa lelang adalah penjualan barang di muka umum dengan cara penawaran harga secara lisan dan atau tertulis melalui usaha pengumpulan peminat atau calon pembeli. ${ }^{10}$

Definisi lainya juga terdapat dalam Pasal 1 Peraturan Menteri Keuangan Republik Indonesia Nomor.27/PMK.06/2016 tentang Petunjuk Pelaksanaan Lelang, disebutkan lelang adalah penjualan barang yang terbuka untuk umum dengan penawaran harga secara tertulis dan/atau lisan yang semakin meningkat atau menurun untuk mencapai harga tertinggi, yang didahului dengan pengumuman lelang. ${ }^{11}$

Berdaasrkan uraian tersebut, dapat diketahui bahwa lelang itu haruslah dilakukan di muka umum dan diumumkan melalui media massa maupun media elektronik serta adanya peserta lelang yang berasal dari beberapa masyarakat yang berminat terhadap barang-barang rampasan yang akan dilakukan pelelangan dan adanya penawaran harga dari barang rampasan tersebut.

${ }^{10}$ Lihat Pasal 1 sub 17 Undang-Undang Nomor 19 Tahun 2000 tentang Penagihan Pajak dengan Surat Paksa

${ }^{11}$ Lihat Pasal 1 Peraturan Menteri Keuangan Republik Indonesia Nomor.27/PMK.06/2016 tentang Petunjuk Pelaksanaan Lelang 
Lelang mengandung unsur-unsur yang tercantum dalam defenisi jual beli adanya subjek hukum, yaitu penjual dan pembeli, adanya kesepakatan antara penjual dan pembeli tentang barang dan harga. adanya hak dan kewajiban yang timbul antara pihak penjual dan pembeli.

Penjualan lelang memiliki identitas dan karakteristik sendiri, dengan adanya pengaturan khusus dalam Vendu Reglement, Vendu Reglement (Stbl. Tahun 1908 Nomor 189 diubah dengan Stbl. 1940 Nomor 56) yang masih berlaku sebagai dasar hukum lelang, yang menyatakan:

"Penjualan umum adalah pelelangan atau penjualan barang-barang yang dilakukan kepada umum dengan harga penawaran yang meningkat atau menurun atau dengan pemasukan harga dalam sampul tertutup, atau kepada orang-orang yang diundang atau sebelumnya diberitahu mengenai pelelangan atau penjualan itu, atau diizinkan untuk ikut serta, dan diberi kesempatan untuk menawar harga, menyetujui harga yang ditawarkan atau memasukkan harga dalam sampul tertutup".

Kemudian, menurut Roell sebagaimana dikutip Rochmat Soemitro menyatakan bahwa penjualan umum adalah suatu rangkaian kejadian yang terjadi antara saat mana seseorang hendak menjual sesuatu atau lebih dari satu barang, baik secara pribadi maupun dengan perantaraan kuasanya, memberikan kesempatan kepada orang-orang yang hadir melakukan penawaran untuk membeli barang-barang yang ditawarkan sampai kepada saat di mana kesempatan lenyap. Jelasnya pendapat tersebut menitik beratkan pada kesempatan penawaran barang. ${ }^{12}$

Lelang sebagai alternatif cara penjualan barang telah cukup lama dikenal, namun pada umumnya pengertian yang dipahami masih rancu karena sering dicampuradukkan dengan konsep lelang pengadaan barang atau jasa dalam rangka pelaksanaan Anggaran Pendapatan dan Belanja

${ }^{12}$ Rochmat Soemitro, Peraturan dan Instruksi Lelang, edisi kedua, Bandung : Penerbit PT Eresco Bandung, 1987, hlm 107. 
Negara (APBN). Lelang tender yang sering dikenal dengan lelang atas pemborongan ini diatur dalam Keputusan Presiden Nomor 16 Tahun 1994 tentang Pelaksanaan APBN. Dalam kaitan ini pembeli (pemerintah) berhadapan dengan penjual yang menawarkan barang/jasa.

Adapun pengertian lelang yang dipakai saat ini di Indonesia menurut peneliti adalah cara penjualan barang di muka umum yang dilaksanakan oleh atau sistem lelang dihadapan pejabat lelang dengan cara pembentukan harga kompetitif melalui penawaran harga secara terbuka/lisan atau tertutup/tertulis yang didahului dengan pengumuman lelang.

Lelang dilaksanakan pada waktu dan tempat tertentu, dan harus didahului dengan pengumuman lelang, serta harus dihadiri oleh peserta lelang, pemohon lelang, pemandu lelang, dan pejabat lelang. Lelang di Indonesia harus dilakukan dihadapan pejabat lelang dari Kantor Lelang Negara kecuali ditentukan lain dengan peraturan pemerintah.

Dengan demikian atas pengertian lelang diatas, maka terdapat unsurunsur yang melakat pada pengertian lelang, yaitu $:^{13}$

4.1.1. Penjualan barang (tender pengadaaan barang dan/atau jasa tidak termasuk dalam pengertian ini.)

4.1.2. Dilakukan dihadapan umum dengan cara mengumumkannya melalui media massa.

4.1.3. Pembeli belum diketahui sebelumnya.

4.1.4. Penawar dengan harga tertinggi akan ditunjuk sebagai pembeli.

4.1.5. Dilakukan dengan cara penawaran yang khusus.

4.1.6. Dilakukan pada suatu saat dan tempat tertentu.

13 Adwin Tista, "Jurnal Perkembangan Sistem Lelang di Indonesia", Volume 5 Nomor $10,2013$. 


\subsection{Asas-asas lelang dalam hukum positif Indonesia}

Setelah mengetahui definisi lelang, maka lebih jauh kedalam juga harus mengetahui tentang prinsip atau asas-asas yang berkaitan dengan lelang yang berlaku di Indonesia yaitu :

\subsubsection{Asas transparansi}

Transparansi atau keterbukaan ini merupakan asas yang paling penting yang membangun peraturan lelang, artinya tidak ada yang disembunyikan, masyarakat diperlakukan sama untuk ikut bersaing membeli barang. Tujuan dari asas transparansi itu sendiri adalah agar asas yang lain terutama asas kompetisi dapat berjalan, yaitu agar terjadi kompetisi yang adil. Dengan adanya kompetisi, diharapkan harga barang menjadi lebih bagus. Selain itu juga bertujuan untuk pertanggungjawaban lelang, karena adanya kontrol dari masyarakat (built in control) sehingga jika ada keberatan, masyarakat dapat mengajukan protes.

Wujud dari asas transparansi adalah pengumuman, lelang harus diumumkan kepada publik agar tidak melanggar asas transparansi dan agar barang yang dilelang dapat cepat terjual. Jika transparansi tidak dilakukan lelang dapat digugat dan dapat dibatalkan karena cacat hukum. Peserta lelang dapat meminta penjelasan dari Pejabat Lelang dan/atau pemilik barang atau pemohon lelang mengenai antara lain harga, barang, dan waktu pelelangan. Dalam hal ini penjelasan tidak mutlak, tergantung barang, jika barang yang akan dilelang tidak termasuk barang mahal, maka penjelasan dari Pejabat Lelang tidak akan diperlukan oleh peserta lelang. Keterbukaan informasi dari Pejabat Lelang berkaitan dengan objek yang akan dilelang dalam arti Pejabat Lelang bersedia menjawab segala pertanyaan yang diberikan peserta lelang mengenai barang yang akan dilelang. 


\subsubsection{Asas kepastian.}

Lelang dilakukan oleh pejabat umum (pemerintah) yang menjual untuk dan atas nama negara. Oleh karena itu harus ada kepastian untuk melindungi rakyat. Asas kepastian mencakup apakah lelang jadi terlaksana atau tidak, tempat pelaksanaan lelang serta berkaitan dengan uang jaminan yang sudah dibayarkan calon pembeli apabila lelang tidak jadi atau dibatalkan pelaksanaannya.

\subsubsection{Asas kompetisi.}

Kompetisi artinya para peserta lelang baik perorangan ataupun badan hukum memiliki hak yang sama untuk bersaing untuk memperoleh barang yang dilelang dengan harga yang setinggi tingginya. Asas ini diterapkan dan akan memberikan pengaruh sangat optimal setelah asas transparansi dan asas kepastian sudah berjalan dengan baik dan pemimpin lelang juga menguasai ilmu barang sehingga dapat memandu jalannya penawaran secara dinamis.

\subsubsection{Asas efisiensi.}

Asas ini berkaitan dengan waktu, dimana lelang dilakukan pada suatu tempat dan waktu yang telah ditentukan dan transaksi terjadi pada saat itu juga. Lelang merupakan penjualan tanpa perantara dalam mencari pembeli secara cepat dan barang terjual cepat. Disamping itu, pembayaran harga lelang juga harus tunai yaitu tiga hari kerja setelah lelang dilakukan sehingga terdapat efisiensi waktu.

\subsubsection{Asas akuntabilitas.}

Lelang harus dilakukan dihadapan Pejabat Lelang yang merupakan pejabat umum yang diangkat oleh Menteri Keuangan dan hasilnya harus dituangkan dalam risalah lelang oleh pejabat lelang sebagai bukti pelaksanaan lelang. Artinya, pelaksanaan lelang harus 
dapat dipertanggungjawabkan. Dalam hal ini Pejabat Lelang harus bersifat imparsial yaitu tidak boleh memihak. ${ }^{14}$

\subsection{Jenis-jenis lelang dalam hukum positif Indonesia}

4.2.1. Lelang eksekusi

Lelang eksekusi adalah lelang untuk melaksanakan putusan/penetapan pengadilan atau dokumen-dokumen lain yang sesuai dengan peraturan perundang-undangan yang berlaku, dipersamakan dengan itu, dalam rangka membantu penegakan hukum antara lain:

\subsubsection{Lelang eksekusi Panitia Urusan Piutang Negara (PUPN).} Lelang Eksekusi Panitia Urusan Piutang Negara (PUPN) adalah pelayananan lelang yang diberikan kepada Panitia Urusan Piutang Negara (PUPN)/Badan Urusan Piutang dan Lelang Negara (BUPLN) dalam rangka proses penyelesaian pengurusan piutang Negara atas barang jaminan/sitaan milik penanggung hutang yang tidak membayar hutangnya kepada negara atas barang berdasarkan Undang-Undang Nomor 49 Tahun 1960 tentang Panitia Pengurusan Piutang Negara. Lelang benda yang berasal dari sitaan yang dilakukan oleh BUPN yaitu hasil lelang dari benda-benda jaminan si debitur kepada badan pemerintah atau kepada BUMN atau kepada BUMD, dan sebagainya.

\subsubsection{Lelang eksekusi pengadilan.}

Lelang eksekusi Pengadilan Negeri (PN)/Pengadilan Agama (PA) adalah lelang yang diminta oleh panitera PN/PA untuk melaksanakan keputusan hakim pengadilan

${ }^{14}$ Adwin Tista, "Jurnal Perkembangan Sistem Lelang di Indonesia", Volume 5 Nomor 10, 2013. 
yang telah berkekuatan pasti, khususnya dalam rangka perdata, termasuk lelang hak tanggungan, yang oleh pemegang hak tanggungan telah diminta fiat (persetujuan resmi) eksekusi kepada ketua pengadilan.

4.2.1.3. Lelang eksekusi pajak.

Lelang sita pajak adalah lelang atas sitaan pajak sebagai tindak lanjut penagihan piutang pajak terhadap negara baik pajak pusat maupun pajak daerah. Dasar hukum dari pelaksaan lelang ini adalah Undang-Undang Nomor. 19 Tahun 1997 tentang Penagihan Pajak Dengan Surat Paksa. Dalam praktek, lelang sita pajak lebih sering semacam shock therapy bagi para wajib pajak, agar mereka segera membayar pajak tunggakan yang terhutang. Lelang dari benda sitaan pajak, yaitu harta kekayaaan wajib pajak yang disita oleh juru sita pajak, kemudian dilelang, hasilnya digunakan untuk melunasi pajak yang terutang dan disetor dalam kas negara, sedangkan lebihnya harus dikembalikan kepada wajib pajak. Lelang eksekusi pajak ini tetap dapat dilaksanakan tanpa dihadiri oleh penanggung pajak.

4.2.1.4. Lelang eksekusi harta pailit.

Lelang eksekusi harta pailit adalah Lelang yang dilakukan oleh pejabat lelang kelas I atas perintah putusan Pengadilan Niaga yang dinyatakan Pailit, dalam hal adanya gugatan terhadap suatu Badan Hukum (termasuk Perseroan) dimana debitur tidak dapat membayar utang-utangnya terhadap kreditur. 
4.2.1.5. Lelang eksekusi benda sitaan Pasal 45 Kitab UndangUndang Hukum Acara Pidana (KUHAP).

Lelang barang temuan adalah barang-barang yang ditemukan oleh penyidik dan telah diumumkan dalam jangka waktu tertentu tidak ada yang mengaku sebagai pemiliknya. Barang temuan kebanyakan berupa hasil hutan yang disita oleh penyidik tetapi tidak ditemukan tersangkanya dan telah diumumkan secara patut, tetapi tidak ada yang mengaku sebagai pemiliknya. Lelang barang sitaan adalah lelang terhadap barang-barang yang disita sebagai barang bukti sitaan perkara pidana yang karena pertimbangan sifatnya cepat rusak, busuk, dan berbahaya atau biaya penyimpanannya terlalu tinggi, dijual mendahului keputusan pengadilan berdasarkan pasal 45 Kitab UndangUndang Acara Pidana setelah mendapatkan izin dari ketua pengadilan tempat perkara berlangsung. Uang hasil lelang dipergunakan sebagai bukti dalam perkara.

4.2.1.6. Lelang eksekusi barang rampasan.

Lelang barang rampasan adalah klelang benda yang berasal dari rampasan suatu perkara pidana dan lelang benda rampasan itu hasilnya disetorkan pada kas Negara sebagai hasil penerimaan APBN.

4.2.1.7. Lelang Eksekusi jaminan fidusia.

Lelang eksekusi jaminan fidusia adalah lelang terhadap objek fidusia karena debitor cedera janji atau wanprestasi, sebagaimana diatur dalam Undang-Undang Nomor 42 Tahun 1999 Tentang Jaminan Fidusia. Dalam hal ini kreditor tidak perlu meminta fiat (persetujuan resmi) eksekusi dari Ketua Pengadilan Negeri apabila akan menjual 
secara lelang barang jaminan kredit yang diikat fidusia, jika debitor cedera janji atau wanprestasi.

Lelang Eksekusi barang yang dinyatakan tidak dikuasai atau barang yang dikuasai negara eks kepabeanan dan cukai. Lelang eksekusi barang Direktorat Jenderal Bea dan Cukai (barang tak bertuan) dapat diadakan terhadap barang yang dinyatakan tidak dikuasai, barang yang dikuasai Negara dan barang yang menjadi milik Negara yang merupakan pengelompokan menurut Direktorat Bea dan Cukai. Lelang barang tak bertuan dimaksudkan untuk menyebut lelang yang dilakukan terhadap barang yang dalam jangka waktu yang ditentukan tidak dibayar bea masuknya.

\subsubsection{Lelang non-eksekusi wajib.}

Lelang noneksekusi wajib adalah lelang untuk melaksanakan penjualan barang milik Negara/daerah sebagaimana dimaksud dalam Undang-Undang Nomor. 1 Tahun 2004 tentang Perbendaharaan Negara atau barang milik Badan Usaha Milik Negara/Daerah (BUMN/D) yang oleh peraturan perundang-undangan diwajibkan untuk dijual secara lelang, termasuk kayu dan hasil hutan lainnya dari tangan pertama.

Lelang tersebut antara lain seperti lelang barang Milik Negara/ Daerah, lelang barang milik Badan Usaha Milik Negara/ Daerah, lelang barang milik Badan Penyelenggara Jaminan Sosial, lelang barang milik Negara yang berasal dari aset eks kepabeanan dan cukai, lelang barang gratifikasi, lelang aset properti bongkaran barang milik Negara karena perbaikan, lelang aset tetap dan barang jaminan diambil alih eks bank dalam likuidasi, lelang aset eks kelolaan PT. Perusahaan Pengelola Aset, lelang aset properti eks Badan Penyehatan Perbankan Nasional, lelang Balai Barta 
Peninggalan atas harta peninggalan tidak terurus dan harta kekayaan orang yang dinyatakan tidak hadir, lelang aset Bank Indonesia dll.

\subsection{Pelaksanaan lelang barang rampasan berdasarkan putusan yang telah} berkekuatan hukum tetap yang dilakukan oleh Kejaksaan Negeri Kota

\section{Kediri.}

Dalam pelaksanaan lelang terhadap barang rampasan, telah ada aturan tentang pelaksanaannya, mulai dari penyitaan barang bukti yang telah digunakan sebagai alat bukti untuk penyidik yang dilakukan oleh pihak kepolisian, lalu dilimpahkan kepada pihak Kejaksaan, kemudian dilakukan penyerahan barang bukti ke pihak Pengadilan untuk dilakukan proses lebih lanjut, hingga adanya keputusan hakim yang menyatakan barang yang menjadi barang rampasan tersebut, dirampas untuk dilakukan pelelangan, untuk kepentingan Negara.

Dalam hal pelimpahan perkara ke Pengadilan negeri diatur oleh Pasal 137, 139, 143 KUHAP. Pengadilan Negeri berwenang mengadili, ketua pengadilan negeri menunjuk hakim yang akan menyidangkan perkara pidana yang bersangkutan, lalu selanjutnya proses pengadilan. Setelah itu mengenai penyelesainnya barang rampasan ini diatur didalam surat Edaran Nomor : SE-03/B/B.5/8/1988 tentang Penyelesaian Barang Rampasan, yang menyebutkan bahwa :

4.4.1. Penyelesaian barang rampasan pada umumnya diselesaikan dengan cara dijual lelang melalui KPKNL, kecuali untuk barang-barang rampasan tertentu Jaksa Agung Republik Indonesia dapat menetapkan lain yaitu digunakan bagi kepentingan Negara, sosial atau dimusnahkan.

4.4.2. Setiap satuan barang rampasan dari suatu perkara yang putusan pengadilannya telah memperoleh kekuatan hukum tetap, dalam tenggang waktu 7 hari setelah putusan tersebut diterima 
sudah harus dilimpahkan penanganannya oleh bidang yang menangani sebelum menjadi barang rampasan kepada bidang yang berwenang yakni Bagian Pembinaan Kejaksaan Negeri menyelesaikannya dengan melampirkan salinan vonis dan pendapat hukum. Mengenai hal tersebut diatas diatur didalam Pasal 28 ayat (2) Undang-Undang Nomor. 27 Tahun 1983.

Berdasarkan hasil wawancara dengan Bapak Didi selaku Kasubag (Kepala Seksi Urusan Bagian) Pembinaan di Kejaksaan Negeri Kota Kediri disampaikan bahwa dalam melakukan lelang barang rampasan mengacu pada Peraturan Menteri Keuangan Republik Indonesia Nomor 27/PMK.06/2016 tentang Petunjuk Pelaksanaan Lelang dan juga Keputusan Menteri Keuangan Republik Indonesia Nomor : 36/KMK.04/2002 tentang Jasa Pra Lelang Dalam Lelang Yang Dinyatakan Tidak Dikuasai, Barang Yang Dikuasai Negara dan Barang Yang Menjadi Milik Negara Pada Direktorat Jendral Bea dan Cukai. ${ }^{15}$

Adapun prosedur yang dilaksanakan kejaksaan selaku pihak yang memiliki kewenangan untuk melakukan pelelangan terhadap barang rampasan tersebut adalah sebagai berikut :

4.4.1. Pra lelang.

Pelaksanaan pra lelang itu terdiri beberapa tahapan, antara lain (1). Sebelum dijual lelang barang rampasan perlu mendapatkan izin.(2). Melakukan penentuan kondisi barang rampasan yang dimintakan kepada ahli atau kepada Instansi yang ada relevansinya dengan barang rampasan tersebut. (3). Menentukan harga dasar atau harga limit yang dimintakan kepada Instansi yang berwenang, didasarkan pada kondisi barang rampasan yang telah ditetapkan oleh ahlinya tersebut

${ }^{15}$ Hasil wawancara dengan Didi Kasubag Pembinaan Kejaksaan Negeri Kota Kediri pada tanggal 5 Februari 2018 
dan dilakukan secara tertulis. (4). Selanjutnya mengajukan Permohonan Pelelangan Barang Rampasan ke KPKNL. (5). Menerima Penetapan Jadwal Lelang dari KPKNL.

\subsubsection{Pelaksanaan lelang.}

Adapun prosedur pelaksanaan lelang barang rampasan yang dilakukan oleh pihak kejaksaan dan didampingi pihak dari KPKNL Wilyah Malang adalah sebagai berikut : (1). Penerbitan Keputusan Izin Lelang Barang Rampasan (2). Melakukan pengumuman lelang. (3). Mencari dan mengumpulkan perserta lelang, baik peserta yang bertempat tinggal di wilayah di mana lelang dilaksanakan maupun peserta yang berada di luar wilayah pelaksanaan lelang barang rampasan tersebut. (3). Setelah dilakukannya pengumuman lelang dan adanya peserta lelang yang cukup, maka langkah selanjutnya adalah melaksanakan pelelangan barang rampasan dilaksanakan oleh Panitia Penyelesaian Barang Rampasan oleh pihak Kejaksaan dan didampingi oleh pihak dari KPKNL Wilyah Malang.

4.4.3. Pasca lelang.

Langkah selanjutnya setelah pelaksanaan lelang terhadap barang rampasan itu selesai dilaksanakan, langkah selanjutnya yang harus dilakukan oleh pihak panitia yaitu, melakukan penyetoran dan laporan serta pemberian diberikan oleh pemerintah kepada pihak-pihak atau Panitia Pelaksana Lelang Barang Rampasan.

Biasanya barang yang dilelang oleh Kejaksaan adalah semua barang rampasan yang dilelang Kejaksaan Negeri Kota Kediri itu semua hasil dari kejahatan lalu ada putusan dari Pengadilan Negeri Kota Kediri yang memutuskan barang tersebut dirampas untuk dilelang, barang rampasan 
tersebut juga yang menjadi sarana tindak kejahatan. Sepeda motor dan hp adalah barang-barang yang biasanya dilelang oleh Kejaksaan Negeri Kota Kediri. $^{16}$

Barang yang paling besar dilelang oleh kejaksaan adalah sepeda motor, ini bisa dijadikan kajian dikarenakan Kota Kediri yang notabene sebagai kota yang jauh lebih padat penduduknya, jauh lebih modern dari kota kecilkecil lainnya namun ada kota yang lebih kecil dari Kota Kediri akan tetapi nilai lelang barang rampasannya jauh lebih besar dari Kota Kediri. Intinya tiap daerah nilai lelangnya itu tergantung dari lihat geografis daerahnya, situasi dan kondisi disetiap daerah. ${ }^{17}$

\subsection{Hambatan yang dihadapi oleh Kejaksaan Negeri Kota Kediri dalam melakukan pelaksanaan lelang barang rampasan berdasarkan putusan yang telah berkekuatan hukum tetap}

Dalam melaksanakan suatu peraturan pada dasarnya terdapat faktorfaktor pendukung dan faktor-faktor penghambat. Faktor-faktor pendukung merupakan penunjang bagi terlaksananya pelaksanaan dari sebuah peraturan, sedangkan faktor-faktor penghambat merupakan penghalang bagi terlaksananya sebuah peraturan pada umumnya. Adapun hambatan yang dihadapi Kejaksaan Negeri Kota Kediri dalam pelaksanaan lelang barang rampasan berdasarkan putusan yang telah berkekuatan hukum tetap ini sangat dipengaruhi oleh faktor-faktor sebagai berikut :

16 Hasil wawancara dengan Didi Kasubag Pembinaan Kejaksaan Negeri Kota Kediri pada tanggal 5 Februari 2018

17 Hasil wawancara dengan Didi Kasubag Pembinaan Kejaksaan Negeri Kota Kediri pada tanggal 5 Februari 2018 


\subsubsection{Efektivitas Kinerja KPKNL (Kantor Pelayanan Kekayaan} Negara dan Lelang) Wilayah Malang.

Proses administrasi di KPKNL Wilayah Malang perlu segera diselesaikan agar pelaksanaan lelang barang rampasan berdasarkan putusan yang telah berkekuatan hukum tetap segera dilaksanakan akan tetapi situasi dilapangan berbeda, pihak Kejaksaan Negeri Kota Kediri yang dituntut untuk segera melaksanakan putusan hakim tetapi disisi lain efektivitas kinerja pelayanan dari KPKNL tidak begitu berjalan lancar dikarenakan ketika Kejaksaan Negeri Kota Kediri mengirimkan berkas-berkas atau meminta surat permohonan lelang dengan cara mengirimkan melalui kantor pos atau dengan e-mail tanggapan dari KPKNL begitu lama bahkan bisa sampai 1 (satu) bulan belum juga ada tanggapan sehingga Kejaksaan Negeri Kota Kediri perlu ke KPKNL. Sesampai di KPNKL Wilayah Malang pihak yang bersangkutan yang menangani lelang tersebut masih ada tugas dinas atau masih mengurus lelang ditempat lain, ini juga dikarenakan sedikitnya pegawai di KPKNL Wilayah Malang. Hal inilah yang menjadikan proses adminitrasi di KPKNL tidak segera selesai dan hal ini juga yang menjadi kendala dari Kejaksaan Negeri Kota Kediri.

\subsubsection{Biaya Terhadap Lelang Barang Rampasan.}

Prosedur pelaksanaan lelang barang rampasan berdasarkan putusan yang telah berkekuatan hukum tetap haruslah dilaksanakan sesuai dengan peraturan perundang-undangan yang berlaku agar tidak ada yang merasa dirugikan, masyarakat atau peserta lelang merasakan bahwa pelaksanaan lelang barang rampasan berdasarkan putusan yang telah berkekuatan hukum tetap tersebut dilaksanakan dengan adil dan juga Kejaksaan Negeri Kota Kediri tidak digugat oleh peserta lelang karena sudah melaksanakan lelang tersebut sesuai dengan peraturan perundang-undangan yang berlaku. 
Ketika pelaksanaan lelang barang rampasan berdasarkan putusan yang telah berkekuatan hukum tetap dikatakan telah berhasil dan semuanya sudah selesai, dibalik pelaksanaan tersebut ada kendala yang dihadapi pihak Kejaksaan Negeri Kota Kediri yaitu terkait dengan pembiayaan lelang barang rampasan berdasarkan putusan yang telah berkekuatan hukum tetap.

Setiap pelaksanaan lelang tersebut pastinya perlu adanya biaya yang dibutuhkan, terkadang pelaksanaan lelang dengan biaya yang dimiliki tidak sebanding dengan biaya yang dibutuhkan untuk pelaksanaan lelang atau bisa dikatakan biaya lelang barang rampasan ini tidak mencukupi. Ketika dilakukan wawancara dengan pihak Kejaksaan Negeri Kota Kediri, penulis menyinggung terkait dengan pembiayaan yang disiapkan oleh pemerintah terkait dengan pelaksanaan lelang barang rampasan tersebut dan ternyata biaya yang disiapkan oleh pemerintah hanya 2 juta rupiah, padahal Kejaksaan Negeri Kota Kediri tidak hanya sekedar melaksanakan lelang tetapi juga merawat barang rampasan yang sekiranya barang tersebut mudah hancur contohnya seperti barang rampasan berupa pupuk

Sementara prosedur pelaksanaan lelang barang rampasan tersebut membutuhkan waktu yang cukup lama padahal barang-barang rampasan yang mudah hancur atau rusak tersebut tidak bisa menunggu lama, maka perlu adanya perawatan terhadap barang rampasan akan tetapi kembali lagi dengan pembiayaan yang kurang cukup ini Kejaksaan Negeri Kota Kediri merasa kebingungan mengatasi kendala tersebut.

\subsubsection{Nilai Ekonomis Barang Rampasan.}

Seperti yang telah dijelaskan sebelumnya bahwa kendala yang dihadapi oleh Kejaksaan Negeri Kota Kediri salah satunya terkait dengan pembiayaan lelang dan perawatan barang rampasan, setiap kali Kejaksaan Negeri Kota Kediri melaksanakan lelang barang rampasan 
pastinya membutuhkan biaya, biaya yang dipersiapkan untuk melaksanakan lelang bisa dikatakan tidak cukup, ini tidak sebanding dengan barang rampasan yang akan dilelang pengertian dari tidak sebanding ini melihat dari nilai ekonomis rendah atau nilai jual yang rendah dari barang rampasan yang akan dilelang tersebut.

Barang rampasan yang akan dilelang oleh Kejaksaan Negeri Kota Kediri kebanyakan adalah barang-barang seperti handphone, barang itu sendiri bisa dikatakan tergolong handphone yang sudah tidak layak pakai menurut survey ke outlet penjualan handphone atau menurut KPKNL Wilayah Malang. Hal ini juga menjadikan kendala Kejaksaan Negeri Kota Kediri. ${ }^{18}$

\section{Penutup}

5.1. Pelaksanaan lelang barang rampasan berdasarkan putusan yang telah berkekuatan hukum tetap yang dilakukan oleh Kejaksaan Negeri Kota Kediri selama ini bisa dikatakan sudah sesuai dengan peraturan perundangundangan yang berlaku, namun efektifitas dari pelaksanaan itu sendiri bisa dikatakan tidak terlalu efektif disebabkan oleh lamanya waktu yang dibutuhkan oleh pihak-pihak yang terkait dalam proses penyelesaian suatu lelang terhadap barang rampasan atau terdapat beberapa kendala.

5.2. Hambatan yang menjadi penghalang pelaksanaan lelang barang rampasan berdasarkan putusan yang telah berkekuatan hukum tetap/inkracht merupakan faktor utama yang menghambat efektivitas pelaksanaan lelang barang yang dilakukan oleh Kejaksaan Negeri Kota Kediri, hambatan itu antara lain yaitu tempat KPKNL, Efektivitas kinerja KPKNL Wilayah Malang, biaya terhadap barang rampasan, nilai ekonomis barang rampasan.

${ }^{18}$ Hasil wawancara dengan Didi Kasubag Pembinaan Kejaksaan Negeri Kota Kediri pada tanggal 5 Februari 2018. 


\section{DAFTAR PUSTAKA}

\section{Peraturan Perundang-undangan}

Keputusan Jaksa Agung tanggal 5 Agustus 1988.

Keputusan Menteri Keuangan 36/KMK.04/2002 Jasa Pra Lelang dalam Lelang Barang yang Dinyatakan Tidak Dikuasai, Barang yang Dikuasai Negara dan Barang yang Menjadi Milik Negara pada Direktorat Jenderal Bea dan Cukai.

Peraturan Menteri Keuangan Republik Indonesia Nomor 27/PMK.06/2016 tentang Petunjuk Pelaksanaan Lelang.

Peraturan Menteri Keuangan Nomor 03/PMK.06/2011 tentang Pengelolaan Barang Milik Negara yang Berasal dari Barang Rampasan Negara dan Barang Gratifikasi.

\section{Literatur Ilmiah}

Adwin Tista, "Jurnal Perkembangan Sistem Lelang di Indonesia", Volume 5 Nomor 10, 2013.

C.S.T. Kansil, Pengantar Ilmu Hukum Dan Tata Hukum Indonesia, Cetakan ketiga, Bandung: PN Balai Pustaka ,1980.

Marpaung, Laden, Proses Penanganan Perkara Pidana Cetakan pertama, Jakarta: Sinar Grafika, 2010.

Mahmud Marzuki, Peter, Penelitian Hukum, Edisi Revisi, cetakan ke sembilan, Jakarta : Prenadamedia, 2014.

Mahardhika, Moh. Fajar, Pelaksanaan Pengelolaan Benda Sitaan dan Barang Rampasan Negara oleh Lembaga Rumah Penyimpanan Benda Sitaan Negara (Rupbasan) Kelas I Jakarta Timur, Skripsi, Fakultas Hukum Universitas Andalas Padang, 2017.

Prasetyo, Teguh, Hukum Pidana, cetakan kelima, Jakarta: Rajawali Pers, 2014.

Soemitro, Rochmat, Peraturan dan Instruksi Lelang, edisi kedua, Bandung : Penerbit PT Eresco Bandung, 1987.

Wahyuni, Tri, Tinjauan Tentang Pelaksanaan Pengelolaan Benda Sitaan Negara dan Barang Rampasan Negara di Rumah Penyimpanan Benda Sitaan Negara (Rupbasan) Surakarta, Skripsi, Fakultas Hukum Universitas Sebelas Maret Surakarta, 2008.

\section{Hasil Wawancara dan Observasi}

Hasil wawancara dengan Didi Kasubag Pembinaan Kejaksaan Negeri Kota Kediri pada tanggal 5 Februari 2018. 